\title{
Isolation of endophytic actinomycetes from Syzygium cumini and their antimicrobial activity against human pathogens
}

\author{
Preeti Saini $^{1 *}$, Madhurama Gangwar ${ }^{1}$, Anu Kalia ${ }^{2}$, Narinder Singh ${ }^{3}$ and Deepti Narang ${ }^{4}$ \\ ${ }^{1}$ Department of Microbiology, Punjab Agricultural University, Ludhiana-141004 (Punjab), INDIA \\ ${ }^{2}$ Electron Microscopy and Nanoscience Laboratory, Punjab Agricultural University, Ludhiana-141004 (Punjab), INDIA \\ ${ }^{3}$ Department of Plant Pathology, Punjab Agriculural University, Ludhiana-141004 (Punjab), INDIA \\ ${ }^{4}$ Department of Microbiology, Guru Angad Dev Veterinary and Animal Sciences University, Ludhiana-141004, \\ (Punjab), INDIA \\ *Corresponding author. E-mail: saini.preeti7777@gmail.com
}

Received: July 22, 2015; Revised received: December 16, 2015; Accepted: March 15, 2016

\begin{abstract}
Isolation of endophytic actinomycetes is an important step to screen antimicrobial compounds to curb the threat of drug-resistant strains of human pathogens. Out of the 50 endophytic actinomycetes obtained from surface sterilized root, stem and leaf tissues of Syzygium cumini, 50 isolates (30\%) exhibited antimicrobial activity. Antistaphylococcal activity was displayed by most of the isolates, with maximum percent inhibition by $\mathrm{J}-10$ (Mean of Inhibition Factor=12.12 $\mathrm{mm}^{2}$ ). A total of 8 isolates (4 each) were able to hydrolyse protein (proteinase activity) and solubilize chitin (chitinase activity). Results of thin layer chromatography confirm the production of chloramphenicol family lantibiotic by the isolate $\mathrm{J}-5$. This is the first report providing an insight into untapped endophytic actinomycete milieu of Syzygium cumini yet to be explored which might be a promising source for novel antimicrobial agents.
\end{abstract}

Keywords: Antagonism, Chitinase, Protease, SEM, Syzygium cumini, TLC

\section{INTRODUCTION}

The use of medicinal plants and trees in Ayurveda has been practiced since ancient times. Plants such as Azadirachta indica, Syzygium cumini, Catharanthus roseus, etc. have proven efficacy to inhibit microbial growth and are used as ingredients of various topical medicines universally. Endophytes are microorganisms that colonize internal plant tissues practically being symptomless to their hosts without causing immediate overt negative effect (Stone et al., 2000). As a result of these long-held associations, endophytic microorganisms and plants have developed better information transfer; leading to the hypothesis that plants with an ethnobotanical history are more potent sources of endophytes producing active natural products than other plants. Endophytic actinomycetes have attracted attention in recent years, with increasing reports of isolates from a range of plant types, including crop (Coombs and Franco, 2003; Surette et al., 2003; Strobel et al., 2004; Tian et al., 2007) and medicinal (Taechowisan et al., 2003; Verma et al., 2009; Kumar et al., 2011) plants. The inhibitory activity of these microbes is attributed to their enzyme production abilities viz. cellulase, chitinase and protease. Chitinase -producing microorganisms are known to inhibit fungal growth due to action on chitin or glucan present in these fungal cell walls (Inbar and Chet, 1991). Similarly, the antibacterial activity of actinomycetes could be attributed to production and secretion of murein hydrolases that digest peptidoglycan of bacteria. Likely, in case of yeast cell, the extracellular protease enzyme(s) opens up the protein structure, releasing wall proteins and mannans, and exposing the glucan surface above. The glucanase, which is a part of their cellulolytic activity, then attacks the inner wall and solubilizes the glucan. Among the 23,000 microbially synthesized bioactive secondary metabolites, over 10,000 are being produced by actinomycetes, which represents $45 \%$ of all bioactive metabolites discovered (Subathra et al., 2012).

Out of the 30,000 clinically described diseases, less than one third can be treated symptomatically and only a few can be cured (Kumar et al., 2011). This situation is further complicated by conditions like antibiotic resistance, as widely described in case of Staphylococcus aureus. Thus, there is an urgent need for new antimicrobial agents to combat these resistant pathogens. Syzygium cumini, Indian traditional medicinal plant, possesses diverse health benefits against diabetes, dental issues, digestive disorders, liver trouble and skin ailments. Few investigations have been made on the antimicrobial activities of the endophytic fungi from this plant (Yadav et al., 2014; Jain and Sharma 2015). However, no such reports are available regarding the endophytic actinomycetes isolated from $S$. cumini, to the best of our knowledge. The present study was thus conducted to investigate in vitro antimicrobial potential of 
endophytic actinomycetes associated with S. cumini against pathogenic microbes.

\section{MATERIALS AND METHODS}

Sampling and isolation: Samples of the root, shoot and leaf tissues were collected from twenty randomly selected healthy trees of $S$. cumini from Ludhiana, Punjab $\left(30.9^{\circ}\right.$ North and $75.85^{\circ}$ East; Elevation, 247 $\mathrm{m})$. Root segments were taken $10-15 \mathrm{~cm}$ below the soil line. Samples were placed in plastic bags and brought to the laboratory in an ice-box and used to screen actinomycetes within $48 \mathrm{~h}$ of collection. Isolation of endophytic actinomycetes was done as per Gangwar et al. (2014). The root, stem and leaf segments were washed in running tap water to remove adhered epiphytes and soil debris. After drying under sterile conditions, tissue surfaces were sterilized by using $70 \%$ (v/v) ethanol for $5 \mathrm{~min}$ and sodium hypochlorite solution $(0.9 \% \mathrm{w} / \mathrm{v}$ available chlorine) for $20 \mathrm{~min}$. Surface-sterilized tissues were washed thrice in sterile distilled water. In order to reduce the opportunity for emergence of endophytic fungi from the tissue, the samples were soaked in $10 \% \mathrm{NaHCO}_{3}$ solution for 10 min to disrupt the growth of the fungi. Each root, shoot and leaf was cut into small pieces $(0.5-1.0 \mathrm{~cm})$ and placed on starch casein agar (SCA) medium followed by incubation at $28^{\circ} \mathrm{C}$ for $14-21$ days to record the microbial growth.

Antagonistic effect against pathogenic fungi: The actinomycete isolates were evaluated for their antifungal activity against Aspergillus niger and A. fumigatus, the causative agents of Aspergillosis in humans, by dual-culture in vitro assay (Phuakjaiphaeo and Kunasakdakul, 2015). The endophytic actinomycete strains were cultured on one side of a Petri dish containing the medium and incubated at $30^{\circ} \mathrm{C}$ for 7 days. The mycelial disc ( $5 \mathrm{~mm}$ diam) containing the fungal pathogen was then placed at a $3 \mathrm{~cm}$ distance from each pre-grown actinomycete colony. In the control plates, only fungal bits were placed at one end. All the plates were incubated at $28^{\circ} \mathrm{C}$ for 14 days and colony growth inhibition (\%) was calculated using the following equation: $\left[\left(\mathrm{R}_{1}-\mathrm{R}_{2}\right) / \mathrm{R}_{1}\right] \times 100$, where $\mathrm{R}_{1}$ represents the radial growth of the untreated control and $R_{2}$ represents the radial growth of the treatments. The data were subjected to variance analysis (ANOVA). Separation of mean using least significant difference (LSD) was also applied at $\mathrm{p} \leq 0.05$.

Primary Screening for antibacterial activity: Spread plate method was used for detecting antagonism against 4 pathogenic bacteria: Escherichia coli, Yersinia sp., Klebsiella sp., Staphylococcus aureus and one pathogenic yeast Candida albicans on McConkey, Nutrient and Sabouraud's Dextrose agar respectively. The modified method by James and Mathew (2015) was followed. Actinomycete isolates were allowed to grow in the centre of agar plates for 4-5 days followed by lawn preparation by spreading $0.1 \mathrm{ml}$ of these pathogenic cultures. All plates were again incubated at $28^{\circ} \mathrm{C}$ for $24 \mathrm{hrs}$. The results were recorded as positive $(+)$ or (-) respectively.

Secondary screening for antibacterial activity by agar well diffusion method: The selected actinomycete isolates from primary screening were subjected to secondary screening by agar well diffusion method as described by Varghese et al. (2014). The isolates were inoculated into starch casein broth, and incubated at $28^{\circ} \mathrm{C}$ in a shaker (200-250 rpm) for seven days. Suspension was then removed by centrifuging at $10,000 \mathrm{~g}$ for $15 \mathrm{~min}$. The concentrate obtained from each isolate was tested for their activity against the test pathogens by well diffusion method in respective media plates. Ninety microlitres of culture supernatant was transferred to each $8 \mathrm{~mm}$ dia. well under aseptic conditions and incubated at $28^{\circ} \mathrm{C}$ for five days. Measurements were done in terms of Inhibition Factor that was calculated using the following formula:

$$
\text { Area of Outer Circle-Area of Inner Circle }\left(\mathrm{mm}^{2}\right)
$$

$$
\text { Area of Inner Circle }
$$

Results were then expressed in terms of Mean of Inhibition Factor (MIF).

Determination of enzymatic activity of the endophytic actinomycete isolates

Measurement of chitinase activity: The isolates that tested positive for antimicrobial activity were spot inoculated on the Colloidal Chitin minimal salt (CCMS) agar medium supplemented with $1 \%$ chitin and incubated at $28^{\circ} \mathrm{C}$ for $7-14$ days. The plates were flooded with a solution of $0.5 \%$ Congo red (Taechowisan et al., 2003).

The isolates which showed a zone of hydrolysis were used for quantitative estimation. These were inoculated in CCMS broth supplemented with $1 \%$ chitin and incubated under the constant agitation at $28^{\circ} \mathrm{C}$ for $8-23$ days. Afterwards, the cells were centrifuged $(10,000 \mathrm{~g}$ for $15 \mathrm{~min}$ ) and the supernatant estimation was done using Nelson and Somogyi method (Green et al., 1989).

Measurement of protease activity: Protease producing ability of the antipathogenic isolates was determined on a medium composed of $10 \%$ skim milk powder (Chu, 2007). An isolate was recorded as being a producer of protease if a zone of clearance was observed around its colony post incubation at $28^{\circ} \mathrm{C}$ for four days.

Measuring of the protease activity was done as described by Hayashi et al. (1967). One unit of protease activity was defined as the amount of enzyme required to liberate $1 \mu \mathrm{g}$ of tyrosine per minute under the experimental conditions used.

Units $/ \mathrm{ml} / \mathrm{min}$ enzyme $=\mu \mathrm{mol}$ tyrosine equivalents released $\times$ Reaction volume $(\mathrm{ml}) /$ Sample vol $(\mathrm{ml}) \times$ Time of incubation ( $\mathrm{min}$ )

Carboxy methyl cellulase (CMCase), amidase and lipase activity: Plate estimation for production of CMCase was done using $1 \%$ of carboxy methyl cellulose (CMC, van der Sand et al., 2014). Amidase production 
potential of the selected iaolates was determined using $2 \%$ urea as the source of amide supplement to nutrient agar medium. The lipase production capacity was demonstrated by using the medium as suggested by Gupta et al. (2012). After incubation for 48 hours at $28^{\circ} \mathrm{C}$, appearance of a well visible halo around the colonies was indicative of the enzymatic activities.

In all the above cases Mean Dissolution Factor (MDF) of the enzymatic activity for each isolate was calculated using formula:

Area of Outer Circle-Area of Inner Circle $\left(\mathrm{mm}^{2}\right)$ Area of Inner Circle

Scanning electron microscopic (SEM) studies of the antagonistic effect of potential actinomycete isolate on $\boldsymbol{S}$. aureus cell wall: SEM was performed to observe the effect of actinomycete isolate (J-5) concentrate on the cell wall of $S$. aureus using chemical fixation and liquid osmium fixation technique (Bozzola and Russell, 1996). Sample was fixed in $2.5 \%$ gluteraldehyde solution (fixative) at $4^{\circ} \mathrm{C}$ for 24 hours. After fixation the gluteraldehyde was drained and three washings with $0.1 \mathrm{M}$ sodium cacodylate buffer $(\mathrm{pH} 7.2)$ were performed after the interval of 15 minutes at $4^{\circ} \mathrm{C}$. Wash buffer was drained and $1 \%$ osmium tetraoxide $\left(\mathrm{OsO}_{4}\right)$ was added for $1-2_{1 / 2}$ hours at $4^{\circ} \mathrm{C}$. As $\mathrm{OsO}_{4}$ is slow penetrating solution the sample was placed in liquid osmium tetraoxide for 2 to 3 hours. Later $\mathrm{OsO}_{4}$ solution was drained off followed by three washings with the rinsing buffer solution $(0.1 \mathrm{M}$ sodium cacodylate buffer) for 15 minutes at $4^{\circ} \mathrm{C}$ each. After fixation step dehydration was done by incubating the samples with the ethanol solution of different concentrations starting with $30 \%, 50 \%$ and $70 \%$ ethanol solution each for 15 minutes at $4^{\circ} \mathrm{C}$ (sample can be stored in $70 \%$ ethanol at $4^{\circ} \mathrm{C}$ for three to four days). Then sample was incubated in $80 \%, 90 \%$ and $95 \%$ ethanol solution each for 15 minutes. Sample was further incubated three times in the $100 \%$ ethanol solution each for 20 minutes at room temperature. The solution was drained off at last and sample was placed in the vacuum dessicator overnight, stubbed and sputter coated with gold in E-1010 Ion sputter coater machine to be viewed under Secondary electron imaging mode in Hitachi S-3400N Scanning electron microscope.

Partial characterization and fractionation of isolate J-5 extract by TLC: The culture supernatant was spot inoculated on silica gel 254 aluminium plates along with three antibiotics viz. penicillin, chloramphenicol and ampicillin $(0.2 \%$ solution each). The chromatograms were developed in a glass tank saturated with solvent vapour, using a mobile phase of ethyl acetate:acetic acid:water (6:2:2). Plates were viewed under UV (254nm) light to locate the UV active compounds.

\section{RESULTS AND DISCUSSION}

A total of 50 actinomycete isolates were obtained from the root, leaf and stem tissues of S. cumini trees. It was observed that root segments were predominantly inhabited by the endophytes, as $56 \%$ (28) of the isolates were recovered from this part of the plants. The reason attributed to this is that endophytes gain entry into the host plant mainly from openings or wounded parts of the plant (Kaur et al., 2015). A total of 21 endophytic actinomycetes were isolated from shoot tissues, followed by leaf segments which yielded only 1 isolate. Similar trend was observed by previous researchers. Phuakjaiphaeo and Kunasakdakul (2015) reported that after 4 week of incubation at $30^{\circ} \mathrm{C}, 36$ isolates of endophytic actinomycetes were obtained from different parts of medicinal herb Centella asiatica (L.) Urban. The majority were isolated from nodes with roots $(n=9,25.0 \%)$, followed by leaves $(n=4$, $11.1 \%)$, and fruits $(n=4,11.1 \%)$. In another study, Passari et al. (2015) recovered a total of 42 endophytic actinomycetes from different organs of seven selected medicinal plants. The highest number of isolates $(\mathrm{n}=$ $22,52.3 \%$ ) was isolated from roots, followed by stems $(\mathrm{n}=9,21.4 \%)$, leaves $(\mathrm{n}=6,14.2 \%)$, flowers $(\mathrm{n}=3$, $7.1 \%)$, and petioles $(\mathrm{n}=2,4.7 \%)$. Taechowisan et al. (2003) also stated that roots represent a good territory for endophytic actinomycetes. As far as S. cumini is concerned, only few reports are available regarding the isolation of endophytic actinomycetes. In two of these reports, Rachniyom et al. (2015 a, 2015 b) obtained endophytic actinomycetes, strains GKU $157 \mathrm{~T}$ and GKU $164^{\mathrm{T}}$, from the roots of a $S$. cumini L. Skeels tree. $16 \mathrm{~S}$ rRNA gene sequence analysis revealed that the strains bear resemblance to the genera Actinomadura and Nonomuraea respectively.

Out of 50 isolates, 4 isolates were displaying antagonistic activity against $A$. fumigatus (Table 1 ). The isolate $\mathrm{J}-7$ was exhibiting maximum percent inhibition against $A$. fumigatus (19.66\%). This was followed by J-12, J-13 and J-4 which were displaying percent inhibitions of $17.80,18.41$ and $15.66 \%$ respectively against $A$. fumigatus. None of the isolates was displaying antagonistic activity against $A$. niger. Our results are also in line with Gangwar et al. (2015), who isolated 36 endophytic actinomycetes from root, stem and leaf tissues of Emblica officinalis Gaertn. Six of these isolates were capable of inhibiting $A$. niger growth in vitro. Lesser availability of the reports points towards need for speedy exploration of antagonistic potentials of endophytes from medicinal plants.

Twenty six percent isolates exhibited strong to mild activity against the test bacterial strains in primary screening (Table 1). A total of 11 endophytic actinomycete isolates showed strong inhibitory activity against $S$. aureus which is noteworthy especially where multidrug resistant pathogens are concerned. This sensitivity was followed by Klebsiella $\mathrm{sp}$. (J-4, J-5 and $\mathrm{J}-10$ ) and $E$. coli (J-9 and J-11). In the secondary screening, isolate $\mathrm{J}-10$ revealed maximum inhibition against $S$. aureus $\left(\mathrm{MIF}=12.12 \mathrm{~mm}^{2}\right)$, followed by $\mathrm{J}-2$ $\left(8.76 \mathrm{~mm}^{2}\right)$ and $\mathrm{J}-4\left(8.52 \mathrm{~mm}^{2}\right)$. Isolate $\mathrm{J}-5$ was 
exhibiting maximum inhibition against Klebsiella sp. and $S$. aureus (11.84 and $2.54 \mathrm{~mm}^{2}$ ). Only one isolate (J-6) had the capability to inhibit Yersinia sp. On the other hand, E. coli was suppressed by J-9 and J-11 with MIF values of 0.72 and $1.13 \mathrm{~mm}^{2}$ respectively. Three actinomycete isolates, viz. J-2, J-5 and J-15 were displaying antagonism against $C$. albicans. Out of these, isolate $\mathrm{J}-2$ was displaying maximum inhibition $\left(5.25 \mathrm{~mm}^{2}\right)$, followed by J-15 and J-5 $(\mathrm{MIF}=3.00$ and $2.62 \mathrm{~mm}^{2}$ ), during secondary screening. Our results are in line with Machavariani et al. (2014), who obtained 179 endophytic actinomycete isolates from leaf tissues of 20 medicinal plants. Out of these, 47 isolates were displaying antibacterial activity against $S$. aureus FDA209 P, 55 against $S$. aureus 209P/UF-2, 41 against $S$. aureus (MRSA) and 13 isolates were active against E. coli. Likewise, Passari et al. (2015) tested 42 endophytic actinomycetes from different medicinal plants against 4 human pathogens viz. E. coli, Pseudomonas aeruginosa, S. aureus and C. albicans. They reported the growth inhibition of all the tested pathogens by $2 / 3^{\text {rd }}$ of the isolates. Out of 42 isolates, $22(52.3 \%)$ exhibited antagonistic activity against at least two of the four tested pathogens and all of them were positive against $S$. aureus and E. coli.

It was noticed that Gram-positive bacteria were more susceptible to antibacterial activity of actinomycetes than Gram-negative bacteria. Ability of Gram-negative bacteria to resist antibacterial agents is attributed to presence of an outer membrane of lipopolysaccharide, protein and phospholipids, attached to thin layer of peptidoglycan, that serve as barrier for antibacterial drugs (Struelens, 2003).
A total of 4 endophytic actinomycete isolates ( $\mathrm{J}-1, \mathrm{~J}-4$, $\mathrm{J}-12$ and $\mathrm{J}-13$ ) were producing chitinase, whereby $\mathrm{J}-13$ and $\mathrm{J}-4\left(\mathrm{MDF}=0.45\right.$ and $0.49 \mathrm{~mm}^{2}$ ) gave rapid and better response to colloidal chitin. These four selected isolates when analyzed quantitatively showed an increase in chitinolytic activity till $20^{\text {th }}$ day of incubation after which there was a phase of decline (Table 2). Four other isolates (J-2, J-5, J-8 and J-15) were able to hydrolyze proteins. Similar trend was followed in the liquid medium for the protease production ability of the test actinomycetes (Table 2). Maximum protease activity was exhibited by isolates $\mathrm{J}$ -15 and $\mathrm{J}-8$ which was $0.16 \mathrm{IU}$.

Out of six isolates positive for CMCase production, J-7 was able to carry out CMC degradation to maximum extent with MDF of $3.87 \mathrm{~mm}^{2}$. The CMC hydrolysis by other isolates was in the descending order of J-4, J$5, \mathrm{~J}-6, \mathrm{~J}-3$ and J-2 (3.78, 3.30, 2.23, 1.19, $\left.0.69 \mathrm{~mm}^{2}\right)$. All of the isolates except $\mathrm{J}-3$ and $\mathrm{J}-11$ were able to utilize $2 \%$ urea as a nitrogen source. This represents the ability of the microbes to carry out hydrolysis of amide bond. On the other hand, all the tested isolates showed appreciable lipophilicity. Our results are in conformity with Gayathri and Muralikrishnan (2013) who tested the endophytic actinomycetes from Mangrove plants for their amylase, cellulase, chitinase, lipase and protease production potentials. All the isolates possessed cellulytic and chitolytic activity, while $n=5,1$ and 4 isolates tested positive for amylase, lipase and proteolytic activities respectively. Vijayan et al. (2014) used the enzyme production potential as the basis of endophytic actinomycete classification.

The results of SEM depicted that $S$. aureus culture was

Table 1. Antimicrobial activity of endophytic actinomycetes isolated from S. cumini expressed as mean of inhibition factor (MIF) and percent inhibition.

\begin{tabular}{|c|c|c|c|c|c|c|}
\hline \multirow[t]{2}{*}{ Isolates } & \multicolumn{6}{|c|}{ Pathogenic microorganisms } \\
\hline & $\begin{array}{c}\text { S. aureus } \\
\left(\mathrm{mm}^{2}\right)\end{array}$ & $\begin{array}{c}\text { C. albicans } \\
\left(\mathrm{mm}^{2}\right)\end{array}$ & $\begin{array}{c}\text { Klebsiella sp. } \\
\left(\mathrm{mm}^{2}\right)\end{array}$ & $\begin{array}{l}\text { Yersinia sp. } \\
\left(\mathrm{mm}^{2}\right)\end{array}$ & $\begin{array}{l}\text { E. coli } \\
\left(\mathrm{mm}^{2}\right)\end{array}$ & $\begin{array}{l}\text { A. fumigatus } \\
\text { (\% inhibition) }\end{array}$ \\
\hline $\mathrm{J}-1$ & 2.93 & - & - & - & - & - \\
\hline $\mathrm{J}-2$ & 8.76 & 5.25 & - & - & - & - \\
\hline $\mathrm{J}-3$ & 2.51 & - & - & - & - & - \\
\hline $\mathrm{J}-4$ & 8.52 & - & 4.64 & - & - & 15.66 \\
\hline $\mathrm{J}-5$ & 2.54 & 2.67 & 11.84 & - & - & - \\
\hline $\mathrm{J}-6$ & - & - & - & 1.13 & - & - \\
\hline $\mathrm{J}-7$ & - & - & - & - & - & 19.66 \\
\hline $\mathrm{J}-8$ & 6.56 & - & - & - & - & - \\
\hline J-9 & - & - & - & - & 0.72 & - \\
\hline $\mathrm{J}-10$ & 12.12 & - & 6.79 & - & - & - \\
\hline $\mathrm{J}-11$ & 5.42 & - & - & - & 6.56 & - \\
\hline $\mathrm{J}-12$ & 5.88 & - & - & - & - & 17.80 \\
\hline $\mathrm{J}-13$ & - & - & - & - & - & 18.41 \\
\hline $\mathrm{J}-14$ & 6.66 & - & - & - & - & - \\
\hline $\mathrm{J}-15$ & - & 3.00 & - & - & - & - \\
\hline $\mathrm{p} \leq 0.05$ & 0.28 & 0.32 & 0.75 & - & 0.43 & 0.58 \\
\hline
\end{tabular}


Table 2. Proteolytic and chitinolytic potentials of the actinomycete isolates.

\begin{tabular}{|c|c|c|c|c|c|c|c|}
\hline \multirow{3}{*}{ Isolate } & \multicolumn{2}{|c|}{$\begin{array}{l}\text { Protease estimation } \\
\end{array}$} & \multicolumn{5}{|c|}{ Chitinase estimation } \\
\hline & \multirow{2}{*}{$\begin{array}{c}\text { Mean } \\
\text { of Dissolution } \\
\text { factor } \\
\text { (MDF) }\end{array}$} & \multirow{2}{*}{$\begin{array}{c}\text { Units/mi/min } \\
\text { enzyme } \\
\text { (In broth) }\end{array}$} & \multirow{2}{*}{$\begin{array}{c}\text { Mean } \\
\text { of Dissolution } \\
\text { factor } \\
\text { (MDF) }\end{array}$} & \multicolumn{4}{|c|}{$\begin{array}{c}\text { Units/min enzyme } \\
\text { (In broth) }\end{array}$} \\
\hline & & & & Day 9 & Day 15 & Day 20 & Day 22 \\
\hline $\mathrm{J}-1$ & - & - & 0.29 & 0.63 & 1.57 & 1.69 & 1.15 \\
\hline $\mathrm{J}-2$ & 2.19 & 0.11 & - & - & - & - & - \\
\hline $\mathrm{J}-4$ & - & - & 0.45 & 1.29 & 1.76 & 1.93 & 1.60 \\
\hline $\mathrm{J}-6$ & 1.47 & 0.11 & - & - & - & - & - \\
\hline $\mathrm{J}-8$ & 3.78 & 0.16 & - & - & - & - & - \\
\hline $\mathrm{J}-12$ & - & - & 0.18 & 0.63 & 0.67 & 0.60 & 0.60 \\
\hline $\mathrm{J}-13$ & - & - & 0.49 & 1.64 & 1.59 & 1.66 & 1.54 \\
\hline $\mathrm{J}-15$ & 4.44 & 0.16 & - & - & - & - & - \\
\hline $\mathrm{p} \leq 0.05$ & 0.81 & 0.02 & 0.08 & \multicolumn{4}{|c|}{0.03} \\
\hline
\end{tabular}

showing a deviation from its original coccus and cluster form. Swelling of the cells as well as release of cellular material after disruption of cell wall and cell membrane was also observed (Fig. 1). Further, these cells lost connection with each other and occurred individually. As evident from Fig. 2, a single spot was observed on the silica gel TLC plate in case of J-5 (Rf $=0.87$ ) which corresponds to the spot observed in case of chloramphenicol $(\mathrm{Rf}=0.89)$. On the other hand, ampicillin revealed a spot with $\mathrm{Rf}=0.15$. This shows that our antimicrobial compound of interest is a member of chloramphenicol family.

Isolate $\mathrm{J}-5$ was the most potent actinomycete, which displayed antagonistic activity against three different test bacteria viz. C. albicans, S. aureus and Klebsiella sp. This may be attributed to its chloramphenicol type antibiotic production potential which enhances the

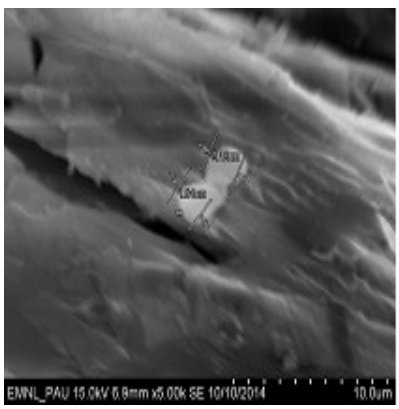

Fig. 1. Scanning electron micrographs showing staphylococcal cell lysis by the isolate $J-5$.

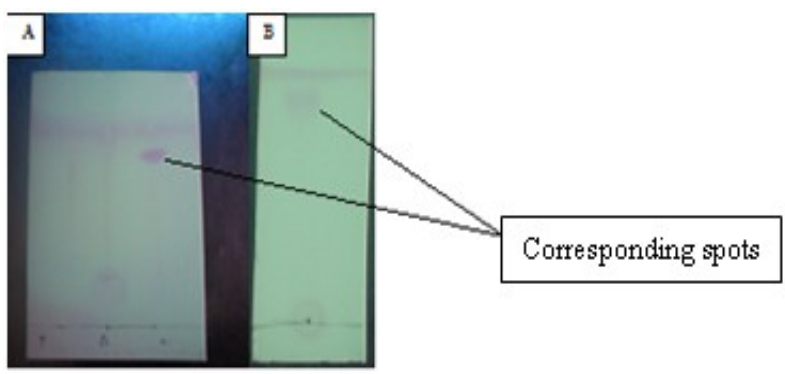

Fig. 2. Thin layer chromatography of three antibiotics and the crude extract of isolate $J-5$. release of lipoteichoic acid and peptidoglycan (Langevelde et al., 1998) as well as prevent protein synthesis by inhibiting peptidyl transferase reaction in bacteria. Also its amidase activity is thought to hydrolyse the amide bond between MurNAc and Lalanine separating the glycan strand from the peptide (Waldemar et al., 2008). Further, there may be a possibility that capsular polysaccharide in $S$. aureus has too been acted upon by its endoglucanase (which is a part of its cellulose degradation potential) and amidase enzymes so that there is separation of cell clusters, as indicated by SEM (Fig. 1). The extracellular proteases of J-4, J-6, J-8 and J-15 are hypothesized to work in a similar manner to that of lysostaphin and Lyt $M$ that cleaves the characteristic pentaglycine crossbridges of $S$. aureus peptidoglycan (Sabala et al., 2012). The outer membrane of lipopolysaccharide present in Klebsiella sp. is also thought to be acted upon by its capability to produce lipase. Similar observations were made by Gayathri and Muralikrishnan (2013) regarding endophytic actinomycete isolates from mangrove trees that presented moderate to good activity against $P$. aeruginosa, E. coli, K. pneumonia, P. vulgaris, S. aureus and $S$. typhi. Antagonism against $C$. albicans by $\mathrm{J}-2, \mathrm{~J}-5$ and $\mathrm{J}-15$ isolates may be attributed to the sequential action of proteases and glucanases released extracellularly.

Similarly, J-4, J-12 and J-13 which were potent producers of chitinase were displaying antifungal activity against $A$. fumigatus (17.80 and $18.41 \%$ respectively). The antifungal activity of $\mathrm{J}-7$ can be attributed to its glucanase release potential, since $\beta-1$, 3 -glucans are major constituents of many fungal cell walls (Sietsma and Wessels, 1979). Various workers have confirmed in vitro lysis of fungal cell walls either by bacterial chitinases or glucanases alone or by a mixture of these enzymes (Ordentlich et al., 1988; Fiske et al., 1990; Ashokvardhan et al., 2014). An important medical use for chitinases has also been recommended in augmenting the activity of anti-fungal drugs in therapy for fungal diseases (Verwer et al., 2013). 


\section{Conclusion}

The present study concluded that $30 \%$ of endophytic actinomycetes of $S$. cumini were active against one or more tested pathogens. Significant antibacterial and antifungal activity of the culture supernatants may be due to the secretion of extracellular enzymes. TLC showed the presence of a compound belonging to chloramphenicol family which may be the active ingredient against test bacteria. On the basis of the present findings, S. cumini endophytic actinomycetes possess the capabilities of being a good candidate in the search for a natural antimicrobial agent against human pathogenic bacteria and fungi. These findings can form the basis for further studies to elucidate the structures of isolated active compounds with the goal to find new therapeutic principles.

\section{REFERENCES}

Ashokvardhan, T., Rajithasri, A.B., Prathyusha, P. and Satyaprasad, K. (2014). Actinomycetes from Capsicum annum L. rhizosphere soil have the biocontrol potential against pathogenic fungi. Int. J. Curr. Micobiol. Appl. Sci., 3(4): 894-903.

Bozzola, J.J. and Russell, D.L. (1996). Electron Microscopy, Second Edition, pp 202-39.

Chu, W.H. (2007). Optimization of extracellular alkaline protease production from species of Bacillus. J. Ind. Microbiol. Biotechnol., 34: 241-245.

Coombs, J.T. and Franco, C.M.M. (2003). Isolation and identification of actinobacteria from surface-sterilized wheat root. Appl. Environ. Microbiol., 69: 5603-5608.

Fiske, M.J., Tobey-Fincher, K.L. and Fuchs, R.L. (1990). Cloning of two genes from Bacillus circulans WL-12 which encode1,3-glucanase activity. J. Gen. Microbiol., 136: $2377-2383$

Gangwar, M., Dogra, S., Gupta, U.P. and Kharwar, R.N. (2014). Diversity and biopotential of endophytic actinomycetes from three medicinal plants in India. Afr. J. Microbiol. Res., 8: 184-191.

Gangwar, M., Kaur, N., Saini, P. and Kalia, A. (2015). The diversity, plant growth promoting and anti-microbial activities of endophytic actinomycetes isolated from Emblica officinalis Gaertn. Int. J. Adv. Res., 3(4): 10621071.

Gayathri, P. and Muralikrishnan, V. (2013). Isolation and characterization of Endophytic Actinomycetes from mangrove plant for antimicrobial activity. Int. J. Curr. Microbiol. Appl. Sci., 2(11): 78-89.

Green, F., Claussen, C.A. and Highley, T.L. (1989). Adaption of the Nelson Somogyi reducing-sugar assay to a microassay using microtiter plates. Anal. Biochem., 182: 197-199.

Gupta, V.K., Kumar, D., Kumar, L., Nagar, S., Raina, C. and Parshad, R. (2012). Screening, isolation and production of lipase/esterase producing Bacillus sp. strain DVL2 and its potential evaluation in esterification and resolution reactions. Archiv. Appl. Sci. Res., 4 (4):17631770.

Hayashi, L.D., Fukushima, D. and Mogi, K. (1967). Agr Biol Chem, Tokyo 31:1237-1241. Cited from Physiology and Parasitism. Edt. by G. P. Agarwal and K. S. Bilgrami. Today and tomorrow's printers and publish- ers, New Delhi, India, pp. 194.

Inbar, J. and Chet, I. (1991). Evidence that chitinase produced by Aeromonas caviae is involved in the biological control of soil-borne plant pathogens by this bacterium. Soil Biol. Biochem., 23: 973-978.

James, D. and Mathew, S. (2015). Antagonistic activity of endophytic microorganisms against bacterial wilt disease of tomato. Int. J. Curr. Adv. Res., 4(10): 399-404.

Kaur, H., Gangwar, M. and Kalia, A. (2015). Diversity of actinomycetes from fodder leguminous plants and their biocontrol potential. Int. J. Adv. Res., 3(8): 1141-1151.

Kumar, U., Singh, A. and SivaKumar, T. (2011). Isolation and screening of endophytic actinomycetes from different parts of Emblica officinalis. Ann. Biol. Res., 2(4): 423434.

Langevelde, P., et al (1998). Antibiotic-induced release of lipoteichoic acid and peptidoglycan from Staphylococcus aureus: Quantitative measurements and biological reactivities. Antimicrob. Agents Chemother., 42: 3073-3078.

Machavariani, N.G., Ivankova, T.D., Sineva, O.N. and Terekhova, L.P. (2014). Isolation of endophytic actinomycetes from medicinal plants of the Moscow Region, Russia. World Appl. Sci. J., 30(11): 1599-1604.

Ordentlich, A., Elad, Y. and Chet, I. (1988). The role of chitinase of Serratia marcescens in biocontrol of Sclerotium rolfsii. Phytopathol., 78: 84-92.

Passari, A.K., Mishra, V.K., Saikia, R., Gupta, V.K. and Singh, B.P. (2015). Isolation, abundance and phylogenetic affiliation of endophytic actinomycetes associated with medicinal plants and screening for their in vitro antimicrobial biosynthetic potential. Front. Microbiol., 6: 273-285.

Phuakjaiphaeo, C. and Kunasakdakul, K. (2015). Isolation and screening for inhibitory activity on Alternaria brassicicola of endophytic actinomycetes from Centella asiatica (L.) Urban. Int. J. Agric. Technol., 11(4): 903912.

Jain, P. and Sharma, P. (2015). Antagonistic activity of endophytic fungi isolated from Syzygium cumini (L.) Skeels. Int. J. Life. Sci. Res., 3(2): 59-63.

Yadav, M., Yadav, A., Kumar, S., Sharma, D. and Yadav, J. P. (2014). Evaluation of in vitro antimicrobial potential of endophytic fungi isolated from Eugenia jambolana Lam. Int. J. Pharm. Pharm. Sci., 6(5): 208-211.

Rachniyom, H., Matsumoto, A., Indananda, C., Duangmal, K., Takahashi, Y. and Thamchaipenet, A. (2015 a). Nonomuraea syzygii sp. nov., an endophytic actinomycete isolated from the roots of a jambolan plum tree (Syzygium cumini L. Skeels). Int. J. Syst. Evol. Microbiol., 65(4): 1234-1240.

Rachniyom, H., Matsumoto, A., Indananda, C., Duangmal, K., Takahashi, Y. and Thamchaipenet, A. (2015 b). Actinomadura syzygii sp. nov., an endophytic actinomycete isolated from the roots of a jambolan plum tree (Syzygium cumini L. Skeels). Int. J. Syst. Evol. Microbiol., 65(6): 1946-1949.

Sabala, I., Jonsson, I.M., Tarkowski, A. and Bochtler, M. (2012). Anti-staphylococcal activities of lysostaphin and LytM catalytic domain. BMC Microbiol., 12: 97107.

Sietsma, J.H. and Wessels, J.G.H. (1979). Cell wall assembly in fungal morphogenesis. NATO ASI Series., 53: 8195. 
Stone, J.K., Charles, W.B. and James, F.W. (2000). An overview of endophytic microbes: endophytism defined. "Microbial endophytes", Marcel Dekker, New York.

Strobel, G., Daisy, B., Castillo, U. and Harper, J. (2004). Natural prod-ucts from endophytic microorganisms. $J$. Nat. Prod., 67(2): 257-268.

Struelens, M.C. (2003). The problem of resistance. In: Finch RG (ed) Antibiotic and chemotherapy: anti-infective agents and their use in therapy, 8th Ed., Elsevier Ltd., Printed in Great Britain, pp. 28.

Subathra. D., Kumari, A. and Jain, N. (2012). Novel bioactive compounds from mangrove derived actinomycetes. Int. Res. J. Pharma., 3(9): 25-29.

Surette, M.A., Sturz, A.V., Lada, R.R. and Nowak, J. (2003). Bacterial endophytes in processing carrots (Daucus carota L. var. sativus): Their localization, population density, biodiversity and their effects on plant growth. Plant Soil., 253: 381-390.

Taechowisan, T., Peberdy, J.F. and Lumyong, S. (2003). Chitinase production by endophytic Streptomyces aureofaciens CMUAc130 and its antagonism against phytopathogenic fungi. Ann. Microbiol., 53: 447-461.

Tian, X.L., Cao, L.X., Tan, H.M., Han, W.Q., Chen, M., Liu, Y.H. and Zhou, S.N. (2007). Diversity of cultivated and uncultivated actinobacterial endophytes in the stems and roots of rice. Microb. Ecol., 53: 700-707. van der Sand, S.T., Minotto, E., Milagre, L.P. and Oliveira, M.T. (2014). Enzyme characterization of endophytic actinobacteria isolated from tomato plants. J. Adv. Sci. Res., 5(2): 16-23.

Varghese, R., Jyothy, S. and Mohamed Hath, A.A. (2014). Diversity and antagonistic activity of actinomycete strains from myristica swamp soils against human pathogens. DOI: 10.2478/acm-2014-0002.

Verma, V.C., Gond, S.K., Kumar, A., Mishra, A., Kharwar, R.N. and Gange, A.C. (2009). Endophytic actinomycetes from Azadirachta indica A. Juss.: Isolation, diversity, and anti-microbial activity. Microb. Ecol., 57(4): 749-756.

Verwer, P.E., Kate, M.T., Falcone, F.H., Morroll, S., Verbrugh, H.A., Bakker-Woudenberg, I.A. and van de Sande, W.W. (2013). Evidence supporting a role for mammalian chitinases in efficacy of caspofungin against experimental aspergillosis in immunocompromised rats. PloS One., http://www.ncbi.nlm.nih.gov/ pubmed/24155872 8(10):e75848.

Vijayan, V.M., Radhakrishnan, M. and Balagurunathan, R. (2014). Bioprospecting of endophytic actinomycetes for antiphytofungal activity. Int. J. ChemTech. Res., 6(5): 2689-2694.

Waldemar, V., Bernard, J., Paulette, C. and Simon, F. (2008). Bacterial peptidoglycan (murein) hydrolases. FEMS Microbiol. Rev., 32: 259-286. 